\title{
Strategi Pengembangan Pemasaran Batu Andesit (Studi Kasus pada PT Duta Keluarga Imfaco, Bogor Jawa Barat)
}

\author{
Development Strategy of Andesite Stone Marketing \\ (Case Study on PT Duta Keluarga Imfaco, Bogor Jawa Barat)
}

Tubagus Imron ${ }^{1^{*}}$, Rizal Syarief Sjaiful Nazli ${ }^{2 *}$, dan Sapta Raharja ${ }^{3 *}$

${ }_{1}^{1}$ Program Magister Pengembangan Industri Kecil Menengah, Sekolah Pascasarjana IPB

${ }^{2}$ Departemen Ilmu dan Teknologi Pangan, Fateta IPB

${ }^{3}$ Departemen Teknologi Industri Pertanian, Fateta IPB

\#Jl. Kamper, Kampus IPB Darmaga, Bogor 16680

\begin{abstract}
ABSTRAK
Kegiatan pertambangan batu andesit di wilayah Bogor kini semakin berkembang, salah satu usaha pengolahan batu andesit adalah PT Duta Keluarga Imfaco yang berada di Kabupaten Bogor Jawa Barat. Batu andesit yang bernilai ekonomis diharapkan menjadi andalan pendapatan masyarakat sekitar, dicirikan dengan semakin banyaknya permintaan pasar dan berkembangnya minat masyarakat terhadap batu andesit. Tujuan penelitian ini adalah (1) Mengidentifikasi faktor internal dan eksternal PT Duta Keluarga Imfaco; (2) Menyusun strategi pengembangan pasar yang tepat; dan (3) Menyusun alternatif strategi pengembangan pemasaran batu andesit. Kajian menggunakan metode deskriptif dan analitik yang bersifat studi kasus. Penentuan responden dengan metode purposive sampling, dengan pertimbangan yang menguasai permasalahan yang akan ditanyakan. Analisis data dengan matriks IFE dan EFE untuk mengidentifikasi faktor internal dan eksternal perusahaan, selanjutnya dilakukan pemetaan dengan matriks IE, untuk melihat posisi perusahaan. Penyusunan strategi dengan matriks SWOT, menghasilkan beberapa alternatif strategi yang dapat diimplementasikan. Tahap akhir dengan matriks QSP, untuk menentukan priotitas strategi yang paling tepat untuk diimplementasikan. Berdasarkan hasil analisis matriks IFE dan EFE, mengindikasikan perusahaan dalam posisi stabil dalam merespon situasi eksternal. Hasil analisis dengan matriks IE, perusahaan berada pada kuadran V, yaitu pertumbuhan dan stabilitas, dimana strategi yang dapat dilakukan adalah penetrasi pasar dan pengembangan usaha. Hasil analisis dengan matriks SWOT didapatkan alternatif strategi yang dapat diimplementasikan dan dengan matriks QSP diperoleh strategi yang paling tepat untuk diimplemen-tasikan dalam rangka pengembangan strategi pemasaran perusahaan adalah memperluas jaringan pemasaran.
\end{abstract}

Kata kunci: batu andesit, pemasaran, strategi pengembangan

\section{ABSTRACT}

Andesite stone mining activities in Bogor area is now growing, one of the andesite stone processing business is PT Duta Keluarga Imfaco located in Bogor Regency, West Java. The economically valuable andesit stone is expected to be the mainstay of the income of the surrounding community, characterized by the increasing market demand and the growing interest of the community towards andesite stone. The purpose of this study are (1) to identify internal and external factors of PT Imfaco Family Ambassador; (2) Developing appropriate market development strategies; and (3) Develop alternative strategies of andesite stone marketing development. The study used descriptive and analytic methods that are case studies. Determination of respondents with purposive sampling method, with consideration that mastered the problems to be asked. Data analysis with IFE and EFE matrix to identify internal and external factor of company, then mapping with IE matrix, to see company position. Preparation of strategy with SWOT matrix, yield several alternative strategies that can be implemented. The final stage with the QSP matrix, to determine the priority of the most appropriate strategy to be

\footnotetext{
*) Korespondensi:

Jl. Babakan Raya No.45, 001/001, Babakan, Dramaga, Kabupaten Bogor, Jawa Barat; email: pt.duta.keluarga.imfaco@gmail.com
} 
implemented. Based on the results of IFE and EFE matrix analysis, indicates the company is in a stable position in responding to external situations. The result of analysis with IE matrix, company is in quadrant $\mathrm{V}$, that is growth and stability, where strategy that can be done is market penetration and business development. Results of analysis with SWOT matrix obtained alternative strategies that can be implemented and with the QSP matrix obtained the most appropriate strategy to be implemented in order to develop the company's marketing strategy is to expand the marketing network.

Key words: andesite stone, development stratetic, marketing

\section{PENDAHULUAN}

Nama andesit disadur dari pegunungan Andes. Ini dikarenakan batuan andesit banyak ditemukan di sekitar pegunungan Andes. Batuan andesit di pegunungan Andes terbentuk sebagai lava "interbeded" bersamaan dengan deposit abu vulkanik (ash) dan tuff di sisi-sisi stratovulcano yang curam. Batuan Andesit atau disebut juga dengan lavastone adalah batuan beku yang tersusun atas mineral yang halus (fine-grained), serta memiliki kandungan silica yang lebih tinggi dari batu basal dan lebih rendah dari batuan rhylolite dan felsite. Hasil penelitian Munaji et al. (2013), menyatakan bahwa nilai tahanan jenis (resistivitas) batuan andesit sebesar 212-300 $\Omega \mathrm{m}$ dengan kedalaman 1,3-1,86 terdapat pada Lintasan 1 dan 2. Hasil uji keteknikan didapatkan nilai rataan tekan uniaksial (UCS) batu andesit 410,93 $\left(\mathrm{kg} / \mathrm{cm}^{2}\right.$ (konstruksi ringan, ketahanan hancur 22,6\% (konstruksi ringan) dan Absortion 1,82\% (konstruksi berat), sehingga batu andesit termasuk dalam kelas III, artinya hanya dapat digunakan sebagai pondasi bangunan dan agregat aduk beton kelas ringan (Hardiyono, 2013). Meskipun pembentukan batuan endosit juga terjadi di bawah permukaan bumi, umumnya batuan endosit terbentuk di permukaan bumi sebagai akibat letusan gunung merapi. Oleh karena itu para ahli mengklasifikasikannya ke dalam bagian batuan beku ekstrusif (Ilmu Geografi 2016).

Batuan Andesit terbentuk dari magma dengan temperatur antara 900 sampai 1.100 derajat celcius. Mineral-mineral yang dikandung batuan andesit bersifat mikroskopis, sehingga tak bisa dilihat tanpa batuan mikroskop. Materialmaterial itu (Ilmugeografi 2016) antara lain (1) silika (SiO2) dengan jumlah antara 52-63\%, (2) kuarsa dengan jumlah sekitar $20 \%$, (3) biotite, (4) basalt, (5) feltise, (6) plagiocase feldspar, (7) pyroxene (clinopyroxene dan orthopyroxene), dan (8) hornblende dengan persentase sangat kecil. Lebih jauh, energi yang dapat disimpan oleh tumpukan batu andesit sebesar 835,2 kJ dengan durasi charging 50 menit dan durasi discharging 200 menit (Yusup, 2016).

Morfologi batuan andesit dapat dikenali dari warna abu-abu yang dominan sampai merah. Warna ini menandakan kandungan silicanya yang cukup besar. Ciri morfologi lainnya adalah memiliki pori-pori yang cukup padat dan struktur yang sangat pejal. Batu Andesit mampu membuat struktur bangunan menjadi lebih kokoh dan akan menimbulkan kesan dingin yang kuat dan memiliki nilai seni tersendiri (Prasadewo et al., 2016). Namun demikian, struktur kepadatan batuan andesit masih dibawah batuan granit. Batuan Andesit berbentuk kristalin. Terdapat beberapa macam kristal mineral pada batuan andesit. Kristal-kristal ini sudah terbentuk jauh sebelum proses pembekuan magma terjadi. Karena itu, para ahli geologi bisa mengidentifikasi sejarah perjalanan magma dari kristalin yang terdapat pada batuan andesit. Menurut Purwasatriya (2013), survai geolistrik dapat membantu interpretasi geologi bawah permukaan dengan menggunakan analisis nilai dan kontras resistivitas batuan. Kristal-kristal penyusun batuan andesit memiliki dua ukuran. Perbedaan ukuran ini terjadi karena magma yang keluar ke permukaan bumi belum sempat terkristal akan terkristal dengan cepat karena suhu permukaan yang rendah. Hasilnya adalah dua kristal dengan ukuran yang berbeda, yaitu: (1) fenokris adalah kristal besar yang sudah terbentuk perlahan-lahan sejak di bawah permukaan bumi dan (2) groundmass adalah kristal berukuran kecil yang terbentuk dengan cepat di permukaan.

Pada umumnya, jenis kristal-kristal dalam batuan andesit seragam (Fenokris saja atau Groundmass saja). Namun ada kejadian dimana, batuan andesit mengandung keduanya, baik fenokris maupun groundmass. Batuan andosit dengan ciri-ciri seperti ini disebut Andosit Porfiri. Meningkatnya kebutuhan masyarakat terhadap batu andesit menjadikan peluang usaha di sektor ini semakin berkembang. Pemasaran batu andesit merupakan salah satu dari kegiatan-kegiatan pokok yang dilakukan oleh para pengusaha 
dalam usahanya untuk mempertahankan kelangsungan hidupnya, untuk berkembang dan untuk mendapatkan laba. Berhasil tidaknya dalam pencapaian tujuan bisnis tergantung kepada keahlian pengusaha di bidang pemasaran, produksi, keuangan maupun bidang lain. Selain itu tergantung pula pada kemampuan pengusaha untuk mengkombinasikan fungsi-fungsi tersebut agar usaha perusahaan dapat berjalan lancar. Pada dasarnya tujuan dalam mendirikan perusahaan adalah mencari laba semaksimal mungkin. Keberhasilan suatu perusahaan dalam mencapai tujuan itu sangat dipengaruhi oleh kemampuan perusahaan dalam memasarkan produknya. Perusahaan dapat menjual produknya dengan harga yang menguntungkan pada tingkat kualitas yang diharapkan, akan mampu mengatasi tantangan dari para pesaing terutama dalam bidang pemasaran.

Oleh karena itu untuk menarik konsumen melakukan pembelian maka perusahaan harus bisa menerapkan strategi pemasaran yang tepat sesuai dengan kondisi pasar yang dihadapi. Keberhasilan strategi pemasaran dipengaruhi oleh beberapa faktor, yaitu riset dan analisa pasar, keputusan tentang produk, penetapan harga, promosi dan distribusi (marketing mix). Kegiatan pertambangan batu andesit di wilayah Bogor kini semakin berkembang, salah satu usaha pengolahan batu andesit adalah PT Duta Keluarga Imfaco yang berada di Kabupaten Bogor Jawa Barat. Batu andesit yang bernilai ekonomis diharapkan menjadi andalan pendapatan masyarakat sekitar, semakin banyaknya permintaan pasar dan berkembangnya minat masyarakat terhadap batu andesit tersebut, maka peneliti tertarik melakukan penelitian Strategi Pengembangan Pemasaran Batu Andesit pada PT Duta Keluarga Imfaco, Bogor Jawa Barat.

Tujuan penelitian adalah (1) Mengidentifikasi faktor internal dan eksternal yang dilakukan PT Duta Keluarga Imfaco; (2) Menyusun strategi pengembangan pasar yang tepat; dan (3) Menyusun alternatif strategi pengembangan pemasaran batu andesit pada PT Duta Keluarga Imfaco.

\section{METODE PENELITIAN}

Kajian ini menggunakan metode deskriptif dan analitik yang bersifat studi kasus. Untuk mengindentifikasi makna dan implikasi dari masalah yang ingin dipecahkan, yaitu fenomena tentang pemasaran dan evaluasi lingkungan (internal dan eksternal) dilakukan wawancara langsung dengan responden menggunakan kuesioner. Penentuan responden yang dipilih untuk mengisi kuesioner dilakukan dengan purposive sampling, yaitu responden ditentukan secara sengaja berdasarkan pertimbangan tertentu (Sugiyono, 2012). Responden yang dipilih untuk mengisi kuesioner adalah pemilik perusahaan, manajer produksi dan manajer pemasaran. Hasil identifikasi dianalisis, sehingga dapat diketahui posisi usaha saat ini dan selanjutnya dilakukan penyusunan strategi pemasaran yang dapat diimplementasikan, serta prospek perkembangan usaha ke depan. Skema pelaksanaan penelitian disajikan pada Gambar 1.

\section{Pengumpulan Data}

Data primer adalah data yang diperoleh langsung di lokasi penelitian, baik melalui wawancara maupun observasi. Data yang termasuk data primer pada penelitian ini adalah hasil wawancara mengenai proses dan situasi usaha, serta dokumentasi guna mendukung hasil penelitian. Data Sekunder adalah data yang diperoleh dari literatur, perpustakaan, instansi pemerintah atau swasta serta laporan penelitian. Data yang termasuk dalam data sekunder penelitian ini adalah data yang diperoleh dari beragam pustaka yang menunjang dan berhubungan dengan kajian.

\section{Pengolahan dan Analisis Data}

1. Matriks Internal Factor Evaluation (IFE) dan External Factor Evaluation (EFE)

Matriks IFE dan EFE bertujuan menganalisis faktor lingkungan, baik internal maupun eksternal usaha. Dalam menganalisis faktor-faktor internal, dilakukan klarifikasi sebagai kekuatan dan kelemahan usaha digunakan matriks IFE. Untuk menganalisis faktor-faktor eksternal, diklasifikasikan atas peluang dan ancaman bagi usaha dalam bentuk matriks EFE.

\section{Matriks Internal-External}

Menurut Rangkuti (2008), Matriks InternalEksternal (IE) berisikan sembilan sel yang memperlihatkan kombinasi total nilai terbobot dari matriks IFE dan EFE. Matriks IE digunakan untuk melakukan pemetaan terhadap skor total matriks IFE dan EFE yang dihasilkan dari audit eksternal dan internal perusahaan. Matriks IE terdiri atas dua dimensi, yaitu total skor dari matriks IFE dan total skor dari matriks EFE. Total skor matriks IFE dipetakan pada sumbu $\mathrm{X}$ dengan skor 1,0-1,99 yang menyatakan posisi internal 
adalah lemah, skor 2,0-2,99 posisinya rataan, serta skor 3,0-4,0 adalah posisi kuat.

3. Analisis SWOT

Analisis SWOT adalah identifikasi berbagai faktor secara sistematik untuk merumuskan strategi perusahaan. Analisis ini didasarkan pada logika memaksimalkan kekuatan (strengths) dan peluang (opportunities), namun secara bersamaan dapat meminimalkan kelemahan (weaknesses) dan ancaman (threats). Proses pengambilan keputusan strategik selalu berkaitan dengan pengembangan misi, tujuan, strategik, dan kebijakan usaha.

4. Matriks QSPM

QSPM merupakan hasil keputusan strategis setelah menilai skor kemenarikan (Attractiveness Score atau AS) setiap faktor strategis, baik faktor internal maupun eksternal (Sarkis, 2003).

\section{HASIL DAN PEMBAHASAN}

PT Duta Keluarga Imfaco merupakan perusahaan yang bergerak di bidang mainning. PT. Duta Keluarga Imfaco beralamat di Jalan Raya Bolang No.12. Argapura, Kecamatan Cigudeg, Kabupaten Bogor Jawa Barat. Pemilih perusahaan
Ir. Tubagus Imron dan Hj. Siti Rohani, SE. PT Duta Keluarga Imfaco berdiri sejak tanggal 3 Desember 1991 dan melalui notaris Mohammad Adam SH keluarlah pengesahan Kementerian Hukum dan HAM No. C2.13297.HT.01.01 pada tanggal 8 Desember 1993. Pada tanggal 25 Agustus 2017 dilakukan Akte Perubahan No. 5 oleh notaris Sugi Harianto, SH, MKn.

\section{Faktor-faktor Internal dan Eksternal}

IFE meliputi kekuatan dan kelemahan dilakukan dengan pembobotan dan pemberian rating berdasarkan penilaian yang dilakukan oleh perusahaan. Matriks IFE dapat dilihat pada Tabel 1. Analisis lingkungan internal terdiri dari fungsi manajemen yang meliputi planning, organizing, actuating dan controlling (POAC) pada setiap fungsi bisnis yaitu fungsi sumber daya manusia, fungsi keuangan, fungsi produksi dan operasional dan fungsi pemasaran (Ling, 2013). Matriks EFE meliputi peluang dan ancaman, dilakukan dengan pembobotan dan pemberian rating berdasarkan penilaian yang dilakukan oleh pemilik usaha. Penilaian pembobotan dan pemberian rating

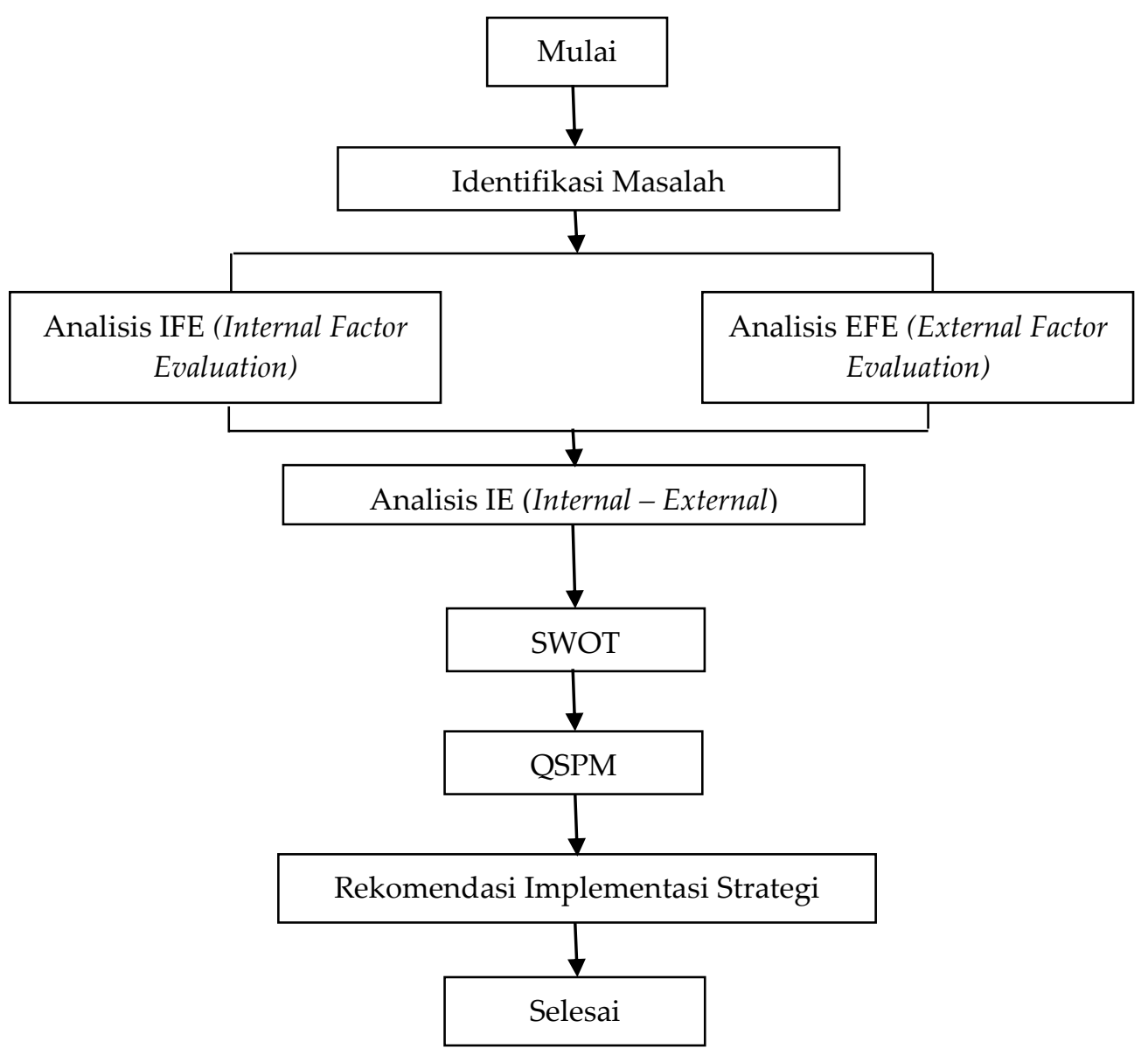

Gambar 1. Diagram alir penelitian 
bersifat subyektif memuat kondisi aktual dan sudut pandang dalam menghadapi berbagai faktor eksternal. Nilai atau skor terbobot total pada evaluasi faktor eksternal akan menentukan posisi usaha dalam menghadapi ancaman berdasarkan peluang yang dimiliki. Dalam hal ini, matriks EFE dapat dilihat pada Tabel 2.

Penilaian pembobotan dan pemberian rating bersifat subyektif memuat kondisi aktual dan sudut pandang dalam menghadapi berbagai faktor internal. Skor terbobot total pada evaluasi faktor internal akan menentukan posisi usaha dalam menghadapi kelemahan berdasarkan kekuatan yang dimiliki.

Berdasarkan hasil penjumlahan skor total pada matriks IFE dan EFE didapatkan nilai masing-masing 2,71 dan 2,82. Skor total yang terdapat pada matriks EFE menggambarkan dan mengindikasikan posisi strategi pengembangan pemasaran batu andesit stabil dalam merespon situasi eksternal yang dihadapi. Skor total IFE mengindikasikan posisi strategi usaha berada pada tingkat rataan untuk mampu merespon iklim internal yang dimiliki.

\section{Penentuan Strategi IE (Internal External)}

Penentuan posisi strategi perusahaan dalam matriks IE didasarkan pada hasil total nilai matriks IFE yang diberi bobot pada sumbu $X$ dan total nilai matriks EFE pada sumbu Y (David, 2006). Berdasarkan pada penilaian matriks IFE dan EFE, posisi perusahaan pada matriks IE berada pada kuadran $\mathrm{V}$, yaitu pertumbuhan dan stabilitas (Gambar 2). Strategi pertumbuhan ini didesain untuk mencapai kondisi pertumbuhan penjualan, pertumbuhan keuntungan dan pertumbuhan aset. Usaha yang dapat dilakukan adalah penetrasi pasar dan pengembangan usaha.

Kegiatan untuk peningkatan pemasaran dan pelayanan merupakan salah satu formulasi strategi yang dapat menjadi andalan utama bagi perusahaan, disamping untuk mengembangkan kegiatan usaha, juga bertujuan untuk mempertahankan usaha, agar terus berlangsung dan

Tabel 1. Perhitungan matriks IFE

\begin{tabular}{|c|c|c|c|}
\hline Faktor Internal & $\begin{array}{l}\text { Bobot } \\
\text { (a) }\end{array}$ & $\begin{array}{l}\text { Rating } \\
\text { (b) }\end{array}$ & $\begin{array}{c}\text { Skor terbobot } \\
(\mathrm{c}=\mathrm{a} \times \mathrm{x})\end{array}$ \\
\hline \multicolumn{4}{|l|}{ Kekuatan } \\
\hline Sistem pemasaran & 0,11 & 4,00 & 0,44 \\
\hline Produksi pengolahan batu andesit & 0,13 & 4,00 & 0,52 \\
\hline $\begin{array}{l}\text { Luas dan besar ruangan produksi yang } \\
\text { disiapkan }\end{array}$ & 0,12 & 3,67 & 0,44 \\
\hline Sistem keuangan & 0,13 & 3,67 & 0,48 \\
\hline \multicolumn{4}{|l|}{ Kelemahan } \\
\hline Sistem manajemen & 0,14 & 1,67 & 0,23 \\
\hline Sistem informasi & 0,10 & 1,67 & 0,17 \\
\hline $\begin{array}{l}\text { Fasilitas dan peralatan yang memadai } \\
\text { untuk produksi }\end{array}$ & 0,16 & 1,67 & 0,27 \\
\hline Kebijakan pemerintah daerah & 0,12 & 1,33 & 0,16 \\
\hline Jumlah & 1 & & 2,71 \\
\hline
\end{tabular}

Tabel 2. Perhitungan matriks EFE

\begin{tabular}{lccc}
\hline \multicolumn{1}{c}{ Faktor Eksternal } & $\begin{array}{c}\text { Bobot } \\
\text { (a) }\end{array}$ & $\begin{array}{c}\text { Rating } \\
\text { (b) }\end{array}$ & $\begin{array}{c}\text { Skorterbobot } \\
\text { (c = a } \mathbf{~} \text { b) }\end{array}$ \\
\hline Peluang & & & \\
\hline Daya tawar pembeli & 0,13 & 4,00 & 0,52 \\
Sistem penerapan teknologi & 0,16 & 4,00 & 0,64 \\
Kondisi demografi penyaluran batu andesit & 0,14 & 3,33 & 0,47 \\
Kebutuhan batu andesit di masyarakat & 0,15 & 3,33 & 0,50 \\
\hline Ancaman & & \multicolumn{2}{c}{0,23} \\
\hline Kondisi ekonomi masyarakat & 0,14 & 1,67 & 0,18 \\
Pendatang usaha sejenis & 0,11 & 1,67 & 0,17 \\
Persaingan antar usaha sejenis & 0,10 & 1,67 & 0,11 \\
Ancaman produk batu lainnya & 0,08 & 1,33 & $\mathbf{2 , 8 2}$ \\
\hline \multicolumn{1}{c}{ Jumlah } & $\mathbf{1}$ & \\
\hline
\end{tabular}


terhindar dari kehilangan penjualan dan kehilangan keuntungan. Hasil identifikasi dari kekuatan, kelemahan, peluang dan ancaman usaha digunakan untuk merumuskan alternatif strategi dengan menggunakan matriks SWOT.

\section{Perumusan Strategi SWOT}

Perumusan strategi diterapkan melalui identifikasi dan analisis faktor-faktor eksternal yang terdiri atas peluang dan ancaman, serta faktor-faktor internal yang berupa kekuatan dan kelemahan. Peluang merupakan situasi yang diinginkan atau disukai dalam lingkungan industri. Ancaman merupakan situasi yang tidak diinginkan atau tidak disukai dalam lingkungan industri. Kekuatan merupakan kompensasi khusus yang memberikan keunggulan komparatif bagi perusahaan, sedangkan kelemahan merupakan keterbatasan atau kekurangan dalam sumber daya keterampilan, maupun kemampuan yang dapat menghambat kinerja perusahaan.

Menurut Rangkuti (2013), hampir setiap perusahaan maupun pengamat bisnis dalam pendekatannya banyak menggunakan analisis SWOT. Analisis ini mengidentifikasi berbagai faktor secara sistematik untuk merumuskan strategi perusahaan. Analisis ini didasarkan pada logika untuk memaksimalkan kekuatan (strengths) dan peluang (opportunities), namun secara bersamaan dapat meminimalkan kelemahan (weaknesses) dan ancaman (threats).

Perumusan strategi dilakukan dengan mengkombinasikan berbagai faktor yang telah diidentifikasi dan dikelompokkan. Hasil perumusan dikelompokkan menjadi empat kelompok perumusan strategi yang terdiri dari strategi Kekuatan-Peluang (S-O), strategi KekuatanAncaman (S-T), Strategi Kelemahan-Peluang (WO) dan strategi Kelemahan-Ancaman (W-T), seperti termuat pada Gambar 3.

Penyusunan mekanisme operasional merupakan batasan kegiatan yang perlu dilakukan oleh perusahaan dalam strategi pengembangan pemasaran batu andesit. Formulasi kebijakan kualitatif pada Gambar 3 dapat dirumuskan sebagai berikut:

\section{Strategi S-O}

Strategi ini didapatkan dengan memanfaatkan dan memaksimalkan kekuatan yang dimiliki untuk mengambil atau memanfaatkan peluang yang ada. Berdasarkan hasil analisis diperoleh beberapa formulasi strategi, yaitu memperluas jaringan pemasaran olahan batu andesit. Kondisi usaha saat ini memiliki tingkat penjualan dan distribusi yang kuat tetapi perlu jaringan pemasaran yang lebih luas sehingga keuntungan dapat terus dioptimalkan. Oleh karena itu, diperlukan upaya untuk meningkatkan produktivitas. Dengan adanya kondisi ini, maka diharapkan perusahaan dapat meningkatkan produktivitas dengan adanya saluran pemasaran yang jelas. Disamping itu, pemilik usaha diharapkan mampu memperkuat permodalan agar dapat bersaing dengan pesaing.

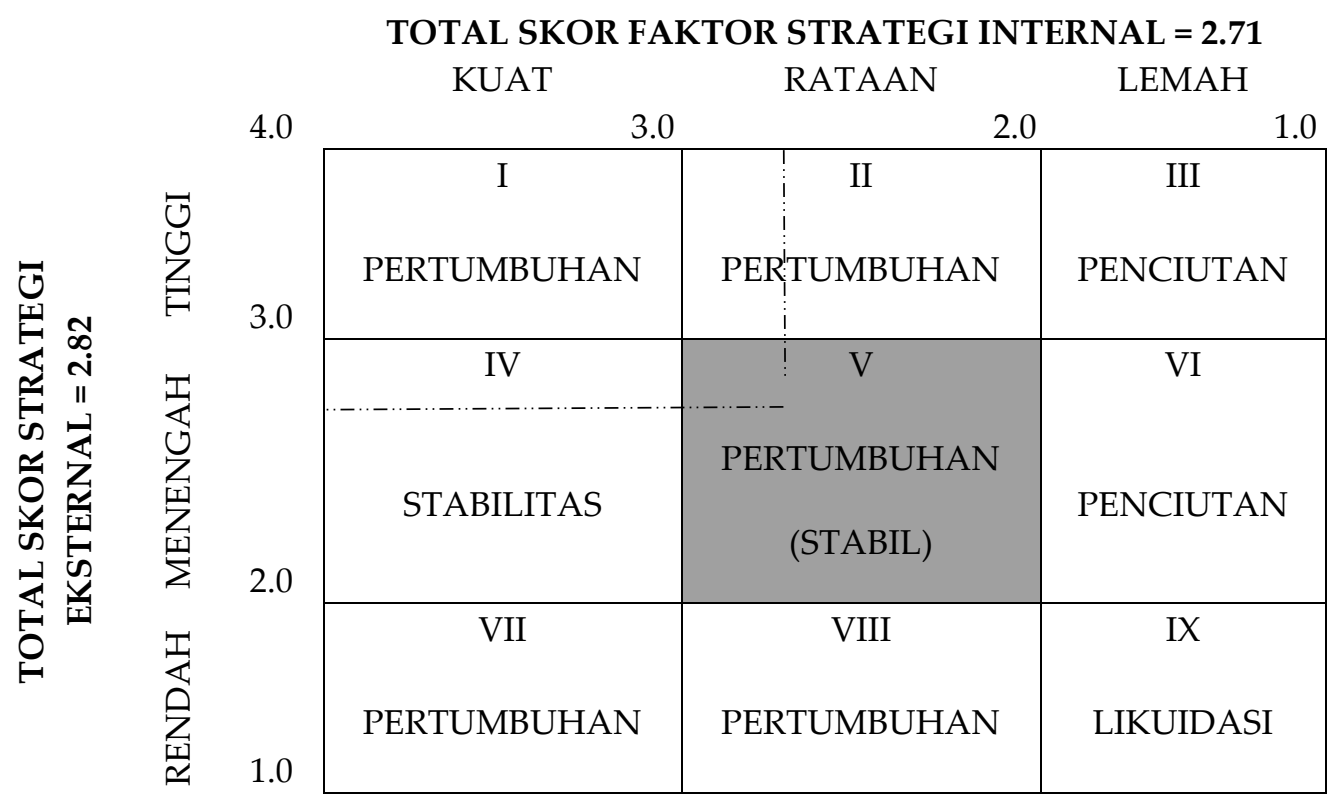

Gambar 2. Analisis Matriks IE 


\begin{tabular}{|c|c|c|}
\hline Faktor Eksternal & $\begin{array}{l}\text { Faktor kekuatan (S) } \\
\text { 1. Sistem pemasaran } \\
\text { 2. Produksi pengolahan batu } \\
\text { andesit } \\
\text { 3. Luas dan besar ruangan } \\
\text { produksi yang disiapkan } \\
\text { 4. Sistem keuangan }\end{array}$ & $\begin{array}{l}\text { Faktor kelemahan }(\mathbf{W}) \\
\text { 1. Sistem manajemen } \\
\text { 2. Sistem informasi } \\
\text { 3. Fasilitas dan peralatan yang kurang } \\
\text { memadai untuk produksi }\end{array}$ \\
\hline $\begin{array}{l}\text { Faktor peluang }(\mathrm{O}) \\
\text { 1. Daya tawar pembeli } \\
\text { 2. Sistem penerapan } \\
\text { teknologi } \\
\text { 3. Kondisi demografi } \\
\text { penyaluran batu andesit } \\
\text { 4. Kebutuhan batu andesit } \\
\text { di masyarakat }\end{array}$ & 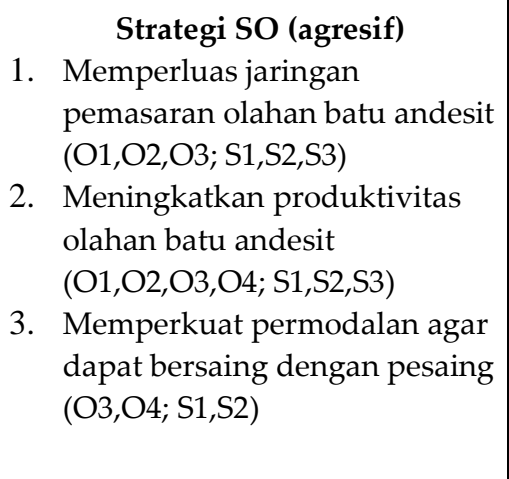 & $\begin{array}{l}\text { Strategi WO (diversifikasi) } \\
\text { 1. Meningkatkan volume penjualan } \\
\text { dengan meningkatkan efektifitas } \\
\text { pemasaran }(\mathrm{O} 1, \mathrm{O} 2, \mathrm{O} 3, \mathrm{O} 4 ; \\
\mathrm{W} 1, \mathrm{~W} 2, \mathrm{~W} 3) \\
\text { 2. Memanfaatkan sistem informasi } \\
\text { dalam meningkatkan penjualan } \\
(\mathrm{O} 2, \mathrm{O} 3, \mathrm{O} 4 ; \mathrm{W} 1, \mathrm{~W} 2, \mathrm{~W} 3) \\
\text { 3. Mengadakan pelatihan dan pening- } \\
\text { katan pengetahuan karyawan } \\
\text { (O2,O3,O4; W1,W2,W3) }\end{array}$ \\
\hline $\begin{array}{l}\text { Faktor ancaman }(\mathrm{T}) \\
\text { 1. Kondisi ekonomi } \\
\text { masyarakat } \\
\text { 2. Pendatang usaha sejenis } \\
\text { 3. Persaingan antar usaha } \\
\text { sejenis } \\
\text { 4. Ancaman produk batu } \\
\text { lainnya } \\
\text { 5. Kebijakan pemerintah } \\
\text { daerah }\end{array}$ & $\begin{array}{l}\text { Strategi ST (diferensiasi) } \\
\text { 1. Konsisten mempertahankan } \\
\text { produktivitas untuk dapat } \\
\text { diterima pasar (T1,T2,T3,T4; } \\
\text { S1,S2,S3) } \\
\text { 2. Meningkatkan pelayanan dan } \\
\text { loyalitas konsumen (T1,T2,T3; } \\
\text { S1,S3) } \\
\text { 3. Meningkatkan kerjasama } \\
\text { dengan pihak lain dalam } \\
\text { bentuk kemitraan pemasaran } \\
\text { (T1,T2,T3,T4,T5; S1,S2,S3,S4) }\end{array}$ & $\begin{array}{l}\text { Strategi WT (defensif) } \\
\text { 1. Meningkatkan teknologi produksi } \\
\text { dan mutu produk (T1,T2,T3; } \\
\text { W1,W2,W3) } \\
\text { 2. Memperbaiki mutu SDM } \\
\text { (T1,T2,T3,T4; W1,W2) } \\
\text { 3. Memanfaatkan kebijakan pemerintah } \\
\text { daerah sesuai kebutuhan masyarakat } \\
\text { (T1,T3,T5; W1,W2,W3) }\end{array}$ \\
\hline
\end{tabular}

Keterangan: (Oi; $\mathrm{Si})$ atau (Oi; $\mathrm{Wi})$ atau $(\mathrm{Ti} ; \mathrm{Si})$ atau (Ti; Wi) menunjukkan kombinasi lingkungan eksternal dengan internal dalam menghasilkan pilihan strategi.

$\mathrm{i}=1,2, \ldots . . . n$.

Gambar 3. Rumusan strategi pemasaran dengan matriks SWOT

\section{Strategi S-T}

Strategi ini didapatkan dengan memaksimalkan kekuatan yang dimiliki perusahaan dalam mengantisipasi ancaman yang ada. Berdasarkan hasil analisis diperoleh beberapa formulasi strategi, yaitu konsisten dalam mempertahankan produktivitas agar dapat diterima pasar, meningkatkan pelayanan dan loyalitas konsumen dan meningkatkan kerjasama dengan pihak lain dalam bentuk kemitraan pemasaran. Usaha saat ini kurang menunjukkan kondisi yang kuat untuk menghadapi ancaman yang ada. Oleh karena itu, strategi yang perlu dilakukan untuk menghadapi persaingan dan pengembangan usaha adalah melakukan pemberdayaan secara optimal terhadap sumber daya yang ada, baik modal, tenaga kerja maupun pengelolaan usahanya. Selain itu, komitmen perusahaan dalam meningkatkan mutu batu yang dihasilkan.

\section{Strategi W-O}

Strategi ini didapatkan dengan usaha menekan atau meminimalisasi kelemahan yang dimiliki perusahaan untuk memanfaatkan peluang yang ada saat ini. Berdasarkan hasil analisis diperoleh strategi meningkatkan volume penjualan dengan meningkatkan efektifitas pemasaran, memanfaatkan sistem informasi dalam meningkatkan penjualan serta mengadakan pelatihan dan peningkatan pengetahuan karyawan di bidangnya. Secara umum, perusahaan memiliki kelemahan yang sama dengan usaha lainnya, yaitu pemasaran masih belum optimal. Pengembangan usaha memiliki peluang sangat besar yang seharusnya mampu ditangkap oleh pemilik usaha, namun demikian strategi yang dapat dilakukan adalah dengan memenuhi tuntutan peluang baik mutu maupun kuantitasnya. Strategi untuk mempertahankan mutu 
adalah dengan pengendalian bahan baku dan pengawasan mutu produksi secara konsisten, dengan tetap diperhatikan dampak dari kegiatan penambangan tersebut, karena dampak penambangan dapat diibaratkan sebagai tekanan negatif terhadap lingkungan sekitarnya dan tekanan lingkungan ini akan memberikan efek pada manusia sebagai bagian dari lingkungan tersebut (Hidayat et al., 2012).

\section{Strategi W-T}

Strategi ini didapatkan melalui upaya meminimalisasi kelemahan yang dimiliki perusahaan untuk mengantisipasi ancaman atau untuk menghadapi kemungkinan ancaman yang ada dari lingkungan eksternal usaha. Berdasarkan hasil analisis diperoleh strategi meningkatkan teknologi produksi dan mutu batu andesit dengan standar mutu yang diinginkan oleh pasar dan memperbaiki mutu SDM serta memanfaatkan kebijakan pemerintah daerah sesuai kebutuhan masyarakat. Kelemahan utama pada usaha ini selain ketersediaan biaya produksi tinggi, juga jaringan distribusi yang masih bersifat lokal. Oleh karena itu, strategi yang dapat dilakukan adalah memperbaiki mutu SDM.

Fokus dari strategi pengembangan pemasaran batu andesit yang dihasilkan untuk penggunaan kekuatan bagi pemanfaatan peluang adalah:

1. Memperluas jaringan pemasaran dengan menggunakan tenaga kerja sesuai keahliannya. Komoditi pertambangan mineral batuan memiliki sifat khusus dalam hal pemasaran yaitu terkait antara lokasi tambang dengan konsumen akhir. Untuk itu diperlukan pola pemasaran dan kemampuan manajerial yang dapat meningkatkan usaha agar lebih kuat. Pola ini mencakup tenaga pemasaran yang handal dan memiliki kemampuan menguasai pasar sesuai dengan bidang usaha pemasaran batu andesit. Selain itu juga harus didukung dengan kemampuan manajerial pemilik usaha, seperti kemampuan mengarahkan tenaga kerjanya dan kemampuan melihat pangsa pasar yang ada.

2. Menciptakan produksi variasi bentuk batu andesit yang lebih baik dengan melihat perkembangan dan keinginan masyarakat luas. Dalam hal ini, pengembangan pemasaran batu andesit yang lebih baik untuk meningkatkan pengembangan usaha, baik dari pemilik maupun tenaga kerja untuk melihat peluang dengan adanya produksi yang lebih baik tersebut, sehingga ada proses timbal balik antara tenaga kerja dan pemilik usaha. Hubungan baik yang terbina akan memperlancar proses produksi dan proses pemasaran.

3. Memperkuat permodalan perusahaan agar dapat bersaing dengan pesaing. Untuk itu diperlukan penambahan modal untuk meningkatkan pangsa pasar. Faktor pasokan modal merupakan peluang usaha dalam meningkatkan kapasitas produksinya.

Memperhatikan peta strategi tersebut, maka pengembangan ke depannya, perusahaan perlu memperhatikan ketepatan dalam menentukan lokasi usaha (kredibel, transportasi, biaya, peraturan dan lainnya), perekrutan tenaga kerja dan hal relevan lainnya untuk meraih keberhasilan usaha.

\section{Analisis QSP}

Penentuan strategi prioritas dengan analisis matriks QSP didasarkan dari hasil alternatif strategi yang dihasilkan dari matriks SWOT kualitatif. Urutan prioritas strategi dari hasil matriks QSP dapat dilihat pada Tabel 3.

\section{Implikasi Manajerial}

Implikasi manajerial yang dapat diaplikasikan PT Duta Keluarga Imfaco dapat dibagi menjadi empat sasaran, yaitu:

1. Pemasaran, dengan menciptakan variasi produk yang disukai konsumen sesuai dengan perkembangan teknologi.

2. Keuangan, dengan memperkuat permodalan agar dapat bersaing dengan pesaing untuk menunjang kegiatan usaha dengan memanfaatkan lembaga perbankan.

3. Produksi, dengan memanfaatkan teknologi untuk meningkatkan mutu produk dan konsisten mempertahankan produktivitas agar diterima pasar.

4. Sumber daya manusia, melalui pelatihan dan pengetahuan karyawan tentang mutu dalam arti umum dan mutu produk untuk meningkatkan produksi dan eksistensi

\section{KESIMPULAN}

Berdasarkan hasil pada matriks IFE dan EFE, mengindikasikan posisi perusahaan berada pada tingkat stabil, mampu merespon situasi eksternal dan pada matriks Matriks IE menunjukkan posisi perusahaan berada di kuadran $\mathrm{V}$ (Pertumbuhan dan Stabilitas), dengan alternatif strategi yang dapat diterapkan yaitu penetrasi 
Tabel 3. Urutan prioritas strategi dari matriks QSP

\begin{tabular}{llc}
\hline No. & \multicolumn{1}{c}{ Alternatif Strategi } & $\begin{array}{c}\text { Total nilai } \\
\text { daya tarik }\end{array}$ \\
\hline 1. & Memperluas jaringan pemasaran olahan batu andesit & 5,94 \\
2. & Meningkatkan pelayanan dan loyalitas konsumen & 5,90 \\
3. & Memperkuat permodalan agar dapat bersaing dengan pesaing & 5,84 \\
4. & Meningkatkan produktivitas olahan batu andesit & 5,80 \\
5. & Meningkatkan teknologi produksi dan mutu produk & 5,79 \\
6. & Meningkatkan kerjasama dengan pihak lain dalam bentuk kemitraan & 5,76 \\
& pemasaran & 5,76 \\
7. & Meningkatkan volume penjualan dengan meningkatkan efektifitas & \\
& pemasaran & 5,51 \\
8. & Memanfaatkan sistem informasi dalam meningkatkan penjualan & 5,43 \\
9. & Konsisten mempertahankan produktivitas untuk dapat diterima pasar & 5,14 \\
10. & Memperbaiki mutu SDM & 4,76 \\
11. & Mengadakan pelatihan dan peningkatan pengetahuan karyawan & 4,34 \\
12. & Memanfaatkan kebijakan pemerintah daerah sesuai kebutuhan \\
& masyarakat & \\
\hline
\end{tabular}

pasar dan pengembangan produk. Berdasarkan hasil perhitungan dalam matriks QSP, diperoleh tiga strategi yang paling tepat diimplementasikan adalah (1) Memperluas jaringan pemasaran olahan batu andesit; (2) Meningkatkan pelayanan dan loyalitas konsumen; dan (3) Memperkuat permodalan agar dapat bersaing dengan pesaing.

\section{DAFTAR PUSTAKA}

Bogdan, R., S.K. Biklen. 1982. Qualitative Research For An Introduction The Teory And Method, Allyn and Bacon, Inc. Boston London (UK).

David, F.R. 2006. Manajemen Strategi (Terjemahan). PT. Prenhallindo, Jakarta (ID).

2011. Manajemen Strategi Konsep. Salemba Empat. Jakarta (ID).

Dyson, R.G. 2003. Strategic Development and SWOT Analysis at the University of Warwick, European Journal of Operational Research. 152(3): 631-640.

Febrianti, O.V., M. Susan. 2013. Usulan Alternatif Strategi PT. X Menggunakan Quantitative Strategic Planning Matrix (QSPM). EJournal Graduate Unpar Part A - Economics. 1 (1): $1-12$.

Hardiyono, A. 2013. Karakteristik Batuan Beku Andesit dan Breksi Vulkanik dan Kemungkinan Penggunaan Sebagai Bahan Bangunan Daerah Ukir Sari, Kecamatan Bojonegoro Kabupaten Serang, Provinsi Banten. Buletin of Scientific Contribution, 11(2): 89-95.
Hidayat, S.P, dan G. Hardiman. 2012. Kajian Kebisingan dan Persepsi Ketergang-guan Masyarakat Akibat Penambangan Batu Andesit Di Desa Jeladri, Kecamatan Winongan, Kabupaten Pasuruan Jawa Timur. Jurnal Ilmu Lingkungan, 2(2): 95-99.

Ilmu Geografi. 2016. Batuan Andesit: Pengertian, Proses dan Manfaatnya. http://ilmugeografi.com/geologi/batuan-andesit. (Diakses 9 Juni 2017).

Ling, A. 2013. Pengelolaan dan Pengembangan Usaha Pada Usaha Mikro Kecil Menengah. Jurnal Agora, 1(1): 1-8.

Miles, M., H.A. Michael. 1992. Analisis Data Kualitatif: Buku Sumber Tantang MetodeMetode Baru (Terjemahan). UI Press. Jakarta (ID).

Munaji, S. Imam, I. Lutfinur. 2013. Penentuan Tahanan Jenis Batuan Andesit Menggunakan Metode Geolistrik Konfigurasi Schlumberger (Studi Kasus Desa Polosiri). Jurnal Fisika, 3(2): 117-121.

Pernando, Y. 2013. Analisis Kelayakan Usaha Galian C (Penambangan Pasir dan Batu) Di Desa Siberakun Kecamatan Benai Kabupaten Kuantan Singingi. Skripsi. Fakultas Ekonomi dan Ilmu Sosial Universitas Islam Negeri Sultan Syarif Kasim Riau. Pekanbaru.

Prasadewo, M.L, A. Rauf, I. Titisariwati, 2016 Potensi serta Neraca Sumberdaya dan Cadangan Batu Andesit di Kabupaten Kulon Progo DI Yogyakarta. Jurnal Teknologi Pertambangan, 1(2): 93-98. 
Purwasatriya, E.B. 2013. Studi Potensi Sumberdaya Andesit Menggunakan Metode Geolistrik Di Daerah Kokap, Kabupaten Kulonprogo, Daerah Istimewa Yogyakarta. Dinamika Rekayasa, 9(2): 54-60.

Rangkuti, F. 2008. SWOT Balance Skorecard. PT. Gramedia Pustaka Utama. Jakarta (ID).
Suparni, N. 1992. Hukum Lingkungan. Sinar Grafika. Jakarta (ID).

Yusup, IM. 2016. Desain Pengering Gabah Berenergi Sekam Menggunakan Batu Basalt dan Andesit Sebagai Media Penyimpan Panas Sensibel. Skripsi pada Departemen Teknik Mesin dan Biosistem Fakultas Teknologi Pertanian Institut Pertanian Bogor. Bogor. 